\title{
The Influence of Cultural Traditions on the Design of the Furniture in the Dressing Room at Puro Mangkunegaran
}

\author{
Atridia Wilastrina ${ }^{1}$, Cama Juli Rianingrum ${ }^{2}$ \\ \{atridia@trisakti.ac.id ${ }^{1}$ \} \\ Department of Interior Design, Faculty of Art and Design, Universitas Trisakti, Jakarta, \\ Indonesia $^{1}$, Department of Interior Design, Faculty of Art and Design, Universitas Trisakti, \\ Jakarta, Indonesia ${ }^{2}$
}

\begin{abstract}
Puro Mangkunegaran is the residence of the king and his family. Puro Mangkunegaran is a picture of nature and a duplicate of the cosmos that has centrifugal power in its environment. Puro Mangkunegaran is full of historical and cultural values and contains functions, meanings, and symbols. For the understanding of functions, meanings, and symbols in this study, the researchers applied the qualitative method. Physically, the interior of Puro Mangkunegaran is equipped with furniture according to its needs, designed using ornaments that have certain cultural and philosophical meanings to maintain a balance between social ethics, cultural ethics, and personal ethics. In everyday life, traditions and ways of behavior related to culture are strongly imbedded in people living in this place. In addition, there are several things of those traditions and behaviors that have an impact on the design of this place. Western cultures also influence the design of the furniture, blending with Eastern culture which is still strongly maintained. One of those applied cultures is the Javanese way of sitting, namely sitting cross-legged on the floor, which becomes a characteristic of daily cultural traditions in the palace (Indonesian: keraton) environment. Results concerning the responses of perception indicate that (1) Javanese cultural behavior and manners, which have religious, philosophical, and cultural meanings, are the response to the expression of people doing it, and (2) cultural procedures in traditional rules influence the design of the furniture used.
\end{abstract}

Keywords: Dressing Room; Furniture; Puro Mangkunegaran; Sitting Crosslegged on the Floor

\section{Introduction}

Puro Mangkunegaran is the witness of the historical journey of the kingdoms in Java Island and is one of the centers for the preservation of customs that have been passed down from generation to generation. A palace or Puro Mangkunegaran is a cultural center, which conceptually places the king as the supreme royal leader. In the order of Javanese culture, ideas, initiatives, and activities are needed in developing traditional Javanese arts. This is 
useful to explain to what extent the weight of action or participation in developing traditional Javanese arts while maintaining the authenticity of Javanese culture. This can be seen from the customs that are still maintained and preserved as the basis of identity. The forms and styles of artistic expression are not solely for the fulfillment of its beauty. It is also comprehensively related to the fulfillment of other needs if referring to the cultural perspective.

Puro Mangkunegaran is a building that resembles the palace where the king and his family live. It represents a picture of nature and is a duplicate of the cosmos that has centrifugal power in its environment. Puro Mangkunegaran, which is full of historical and cultural values, contains full of meanings and symbols. The most complete development of Javanese culture can be seen in this palace (Indonesian: keraton) environment. Inside the palace, it is possible to fully learn Javanese culture, which is full of procedures, rules, and behaviors, developed in the life of the general public. Everything that happens in the palace environment is the main standard of Javanese society [1]. Therefore, the representation of Javanese culture can be seen in the customary pattern and cultural behavior applied in the royal family environment in Puro Mangkunegaran, Surakarta, under the government of Mangkunegara which is the group of people with the highest status. The second-highest layer is the family of Mangkunegara or called sentana dalem. The third layer is the abdi dalem, namely people who work and help in the Puro Mangkunegaran environment. The fourth and lowest layer is the wong cilik or ordinary people [2]. In the development of Javanese culture, Puro Mangkunegaran is highly respected and must be preserved. In the colonial era, Puro Mangkunegaran also established a relationship with the colonial government which exerted a strong influence to inserting elements of European culture in Puro Mangkunegaran. At that time, the influx of Western cultural influences did not necessarily destroy Eastern culture. Puro Mangkunegaran could filter what came from the West without losing Eastern cultural identity by continuing to harmonize European culture and Javanese culture in Surakarta. Therefore, the greatness of the past culture could still be realized in today's packaging as an effort to preserve Javanese culture.

\section{Methods}

In this study, the researchers applied a descriptive-qualitative method with a design approach that describes the influence of acculturation on the design of the dressing room at Puro Mangkunegaran. Puro Mangkunegaran is a traditional Javanese building that has the influence of classic European style on the design of certain spaces. However, people using those spaces still reflect the Javanese cultural tradition by sitting cross-legged on the floor. The approach applied in this study emphasized more on rationalism and the existing cultural realities. This approach attempted to understand culture through the views of the cultural owner or those who practice the culture. Problems examined in this study were cultural and aesthetical aspects of the interior of the dressing room at Puro Mangkunegaran related to spiritual elements and ergonomic factors which have an impact on the design of the room and the furniture used. In this study, data analysis was carried out using the qualitative technique to understand and process the data that had been collected. Data analysis has been conducted from the initial data collection to the writing of the research report. However, the process was also adjusted according to the type of data collected from the field to be analyzed. This study described physical facts of cultural aesthetics with philosophical values in the dressing room at Puro Mangkunegaran. 
The data were obtained through interviews with informants from the family of Mangkunegaran who were very knowledgeable about family matters and manners that affect the design of the dressing room at Puro Mangkunegaran. The following was the approach taken in this study: (1) gathering historical data, (2) interviewing informants, and (3) collecting field data from survey results in the form of photos, articles about Puro Mangkunegaran, and reference books.

\section{Results and Discussion}

\subsection{Cultural Behaviors Applied in the Keraton}

Behaviors applied in life in the keraton environment have been passed down from parents to their children as contained in Serat Centhini consisting of twenty-six knowledge in life [3]. Cultural behaviors have become a pattern in educating children, that is carried out from generation to generation [4], [5]. Behaviors applied in the keraton have existed since children are born in the keraton until they grow up with all the rules that have become a habit in the keraton environment. It runs as it is because of the presence of mbok emban as a caregiver for the king's sons and daughters [6]. Mbok emban is a female abdi dalem who is in charge of nurturing and accompanying the king's children daily. Until the age of adolescence, especially the princesses, abdi dalem will accompany them and help to fulfill all of their needs, such as preparing daily needs, making up, dressing, the need for artistic activities, and body care. All of them are usually carried out in the dressing room functioning as the princess' private room.

\subsection{The Development of the Dressing Room at the Keraton}

In the development of the dressing room at Puro Mangkunegaran, there are several stages of development happening based on the designation of the building which undergoes three stages of changes due to the development of the times and different users from generation to generation. In the first stage, the room was to honor the arrival of the prospective father-in-law of King Mangkunegaran VII, namely King Hamengkubuwono VII. King Hamengkubuwono VII was the father of Gusti Ratu Timur who would be the wife of King Mangkunegaran VII at that time. The room was designated as a guest area equipped with a reception room, dining room, and a private area consisting of a guest bedroom, dressing room, and bathroom. As a private space, only certain people could enter the room because customs and traditions were still strongly applied in the keraton. In the second stage, the dressing room was dedicated to King's only daughter, namely Gusti Nurul. This room was used as a dressing room for carrying out all her activities, including making up, dressing, body care, meditation, and dance practice, in which she was usually assisted by some of her abdi dalem. In carrying out all their activities, abdi dalem had to refer to the order of the rules of cultural traditions in the keraton. As the third level people, they were required to follow the procedures applied in the keraton during carrying out their duties, such as a sitting position, serving as respect symbolization and cultural tradition in the keraton. Before entering the area, they were already kneeling and walking in a squatting manner according to the custom applied in the keraton. This dressing room was used by the daughter of King, namely Gusti Nurul until she became an adult and married. This is what makes this dressing room have a design that is adapted to the behavior of the user with very strong Javanese cultural norms. In the third stage, the designation of this dressing room was no longer as sacred as previously because it was used by the daughter's 
family or close relatives as a place to dress if there was a certain family event, such as a celebration at the keraton or a wedding party. Therefore, several strict cultural traditions were re-adjusted.

\subsection{Ergonomic Aspect and Furniture in the Dressing Room}

In interacting and communicating, Javanese people, especially those living in the keraton environment, must behave politely, be peaceful, be respectful, do not cause conflict, and prioritize the principle of harmony. Therefore, the design of the dressing room at Puro Mangkunegaran must be adjusted with the pattern of etiquette rules to make it easier for users to interact and communicate, especially in dressing activities. The things that influence the design are the Javanese philosophy that remains in it, which has become the soul of the dressing room. As a result, the room contains a strong Javanese spirit. Inherent culture and traditions affect the design which must be is adapted to the users' behavior pattern, such as the use of space in a functional way like sitting cross-legged without using a dressing chair, which ignores the ergonomics factor of the user when dressing. The dressing room at Puro Mangkunegaran also has a meaning or contains Javanese philosophy which is the picture of an order that consists of high cultural values. Behavior in the dressing room at Puro Mangkunegaran usually must be in the manner that describes certain ethics that show respect to avoid all kinds of misfortune. In this dressing room, a princess usually performs certain activities, such as (a) taking care of her body (e.g., scrubs, facial masks, massages, and others), (b) making up, (c) dressing up, (d) styling hair, and (e) meditation in a sitting position. Furthermore, all non-personal activities are usually assisted by three or more abdi dalem, in which the number abdi dalem accompanying the princess is based on her need. In assisting the princess, the abdi dalem must kneel with procedures and behaviors according to the traditional order, such as when entering the room, they must have mental stability (mangu), clear mind (brojonolo), and behave respectfully which describes their degrees like respecting (ngapurancang), sitting cross-legged, and walking while squatting (laku dodok).
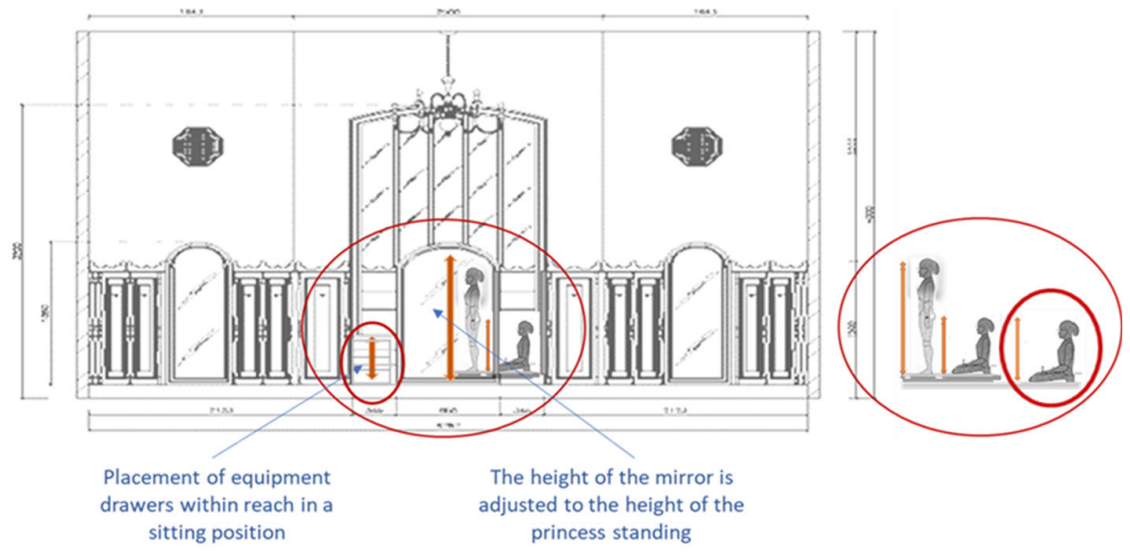

Fig. 1. Ergonomics in the Dressing Room of Puro Mangkunegaran

For the life in the keraton like Puro Mangkunegaran, meditation is a common activity because it is one of the cultures that have existed for a long time there. It aims to manage the mind as a human by sitting quietly under or meditating for getting closer to the God Almighty. 
By managing the mind, it is expected that they can organize their behavior based on the nobility of the mind outwardly and inwardly. According to KRMH Yosodipura [7], the culture applied in the keraton can be called kebudayan karaton (English: the palace culture). The word budaya (culture) means "woh pangolahing budi" or the result of behavior management. This meaning contains two points, namely (1) product (reflected in the word woh or fruit) and (2) process (reflected in behavior management). This culture also affects the physical and nonphysical aspects in the dressing room which cannot be separated because the physical aspect is a container in terms of culture, while the non-physical aspect is related to functions that have symbolic meanings from existing cultural values. Several examples of the non-physical culture are cultural arts, such as dance, music, clothing, and others. Another form is the way of life in Puro Mangkunegaran, such as customs that are upheld. This pattern of cultural behavior has an impact on the design of the furniture, which is adapted to these procedures, in which the design of the furniture is adjusted to the ergonomics of the user. In addition, the furniture must be easily accessible in a sitting position with a maximum height of $60 \mathrm{~cm}$.

A mirror is placed on a wall panel with a height of 170 from the floor. It is to make the princess who is dressing be able to see her body from bottom to top in standing position or sitting cross-legged position. The shape of the dressing room at Puro Mangkunegaran is octagonal in which the length of each wall is 6 meters. 5 of the 8 sides of the room are installed with a mirror so that the princess can see all angles when standing or dressing. In addition, the princess can see her body movement, through the mirrors when practicing dance.

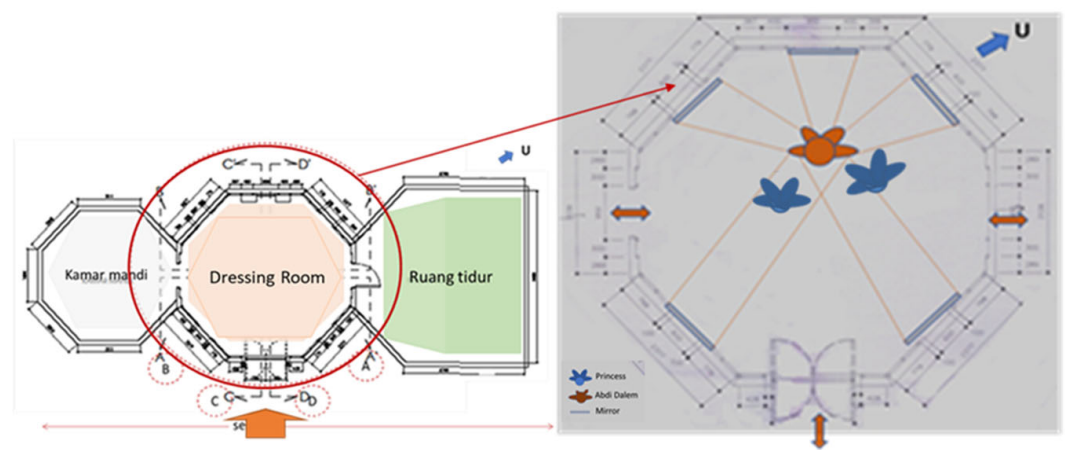

Fig. 2. The Reflection of the Mirrors in the Dressing Room at Puro Mangkunegaran

For using the room as a dressing room, the designated user must follow the Javanese cultural traditions with all the procedures that contain philosophical values. The activity of making up and traditional dressing up the princess of the Mangkunegaran palace with all the activities and facilities according to their needs and ergonomically in traditional clothes. Procedures the Javanese traditional culture by sitting cross-legged below assisted by abdi dalem has an impact on the design of the furniture which tends to be lower so that it is in accordance with the ergonomics of the human body when sitting cross-legged on the floor. Philosophical values that influence the behavior of performs certain activities with designs that describe the manners of how to making up or dressing up a princess are usually assisted by three or more abdi dalem by sitting cross-legged without a dressing chair activity.

The Javanese traditional culture, namely sitting cross-legged while being assisted by several abdi dalem, gives an impact on the design of the furniture which tends to be placed lower so that it is in line with the ergonomics of the human body when sitting cross-legged on 
the floor. Likewise, the position of a princess, who is being assisted by her abdi dalem in a sitting or standing state, results in the location and dimension of the mirror to accommodate the sight of the princess to be able to see the entire of her body from bottom to top.

\subsection{Design Acculturation in the Dressing Room at Puro Mangkunegaran}

At the beginning of the presence of the Dutch in Indonesia, there had been cultural contact which later resulted in a blend of cultures. The mixed culture that was supported by some groups of the Dutch East Indies society is called "Indic Culture". The area of Surakarta was the center of government in Central Java during the colonial period. Puro Mangkunegaran is one of the artifacts that was built with the concept of coping with Indonesia's tropical climate combined with neo-classical elements. In the design of the dressing room at Puro Mangkunegaran, the influence of acculturation can be seen in the classic European-style building by architect Thomas Karsten, as seen in its space and aesthetic elements. The king at that time was Mangkunegaran VII. He was the initiator who had an advanced view because of his high educational background in the Netherlands, making his taste for art influenced by Western art.
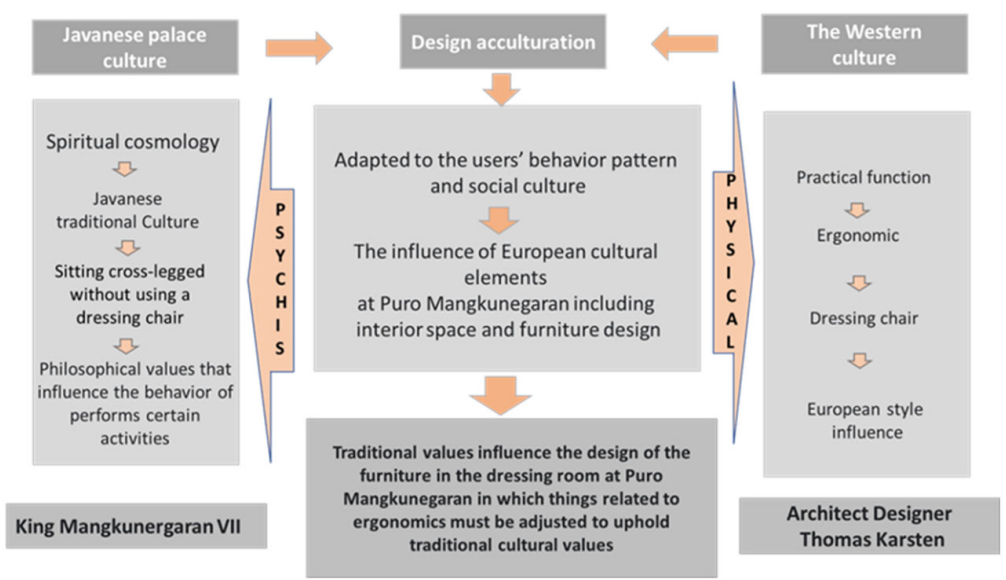

Fig. 3. The Schema of Design Acculturation of the Dressing Room at Puro Mangkunegaran

\section{Conclusion}

In Javanese civilization, many traditional values are still inherent among the Javanese people. It has been instilled in their lives from the past to the present, both mentally and physically. These values in the norms of Javanese life affect the design of furniture used, including as follows: (1) Javanese spiritualism: covering the concepts of theology, mythology, and cosmology according to the Javanese view, (2) Javanese philosophy: containing the teachings/guidance of Javanese life, (3) Javanese cultural behaviors and traditions (customs), (4) Javanese cultural arts (e.g., dance, music, paintings, others), and (5) Javanese language and literature. In its development, these traditional values influence the design of the furniture in the dressing room at Puro Mangkunegaran in which things related to ergonomics must be adjusted to uphold traditional cultural values. As a result, it results in a concept of dressing up 
by sitting cross-legged on the floor. Therefore, its impact is the adjustment of the furniture in the room. As a result of the procedures for user behavior, a design is produced that takes into account the traditional ergonomics factor (sitting cross-legged on the floor because of usually being assisted by several abdi dalem). For this reason, its size must exceed the maximum reach of the human hand. In addition, the size of the mirror is adjusted to the height of the sitting and standing position of the princess in which, the mirror must show the entire body of the princess from the bottom to top.

\section{References}

[1] G. Moedjanto, Konsep Kekuasaan Jawa Penerapannya oleh Raja-Raja Jawa. Yogyakarta: Kanisius, 1987.

[2] A. Surjomihardjo, Sejarah Perkembangan Sosial Kota Yogyakarta 1880-1930. Yogyakarta: Penerbit Yayasan untuk Indonesia, 2000.

[3] Marsono, "wayang Purwa pada Upacara Sadranan di Lingkungan Masyarakat Jawa Tengah,” Universitas Gadja Mada, 1991.

[4] Kuntowijoyo, Tiara Wacana Yogya. Yogyakarta: Tiara Wacana, 1987.

[5] Koentjaraningrat, Manusia Dan Kebudayaan Di Indonesia. Jakarta: Djambatan, 1988.

[6] U. Hermono, Etnisitas, Identitas, dan Kebudayaan. Jakarta: Kompas, 2014.

[7] K. Yosodipura, Nilai-Nilai Tradisi dan Budaya Keraton. Surakarta: Nusantara Surakarta, 1990. 